\title{
A supply chain cost reduction framework for the South African mobile phone industry
}

\begin{tabular}{|c|c|}
\hline $\begin{array}{l}\text { Authors: } \\
\text { Musenga F. M } \\
\text { Cornelius H. v }\end{array}$ & $\begin{array}{l}\text { pwanya }^{1} \\
\text { an Heerden }\end{array}$ \\
\hline $\begin{array}{l}\text { Affiliations: } \\
\text { 1Department } \\
\text { Logistics and } \\
\text { Management, } \\
\text { University of } \\
\text { South Africa }\end{array}$ & $\begin{array}{l}\text { f Marketing, } \\
\text { port } \\
\text { Tshwane } \\
\text { echnology, }\end{array}$ \\
\hline $\begin{array}{l}{ }^{2} \text { Faculty of Ma } \\
\text { Sciences, Offic } \\
\text { Executive Dea } \\
\text { University of } \\
\text { South Africa }\end{array}$ & $\begin{array}{l}\text { nagement } \\
\text { e of the } \\
\text { n, Tshwane } \\
\text { echnology, }\end{array}$ \\
\hline $\begin{array}{l}\text { Correspondin } \\
\text { Musenga Mpv } \\
\text { mpwanyamf }\end{array}$ & $\begin{array}{l}\text { g author: } \\
\text { vanya, } \\
\text { tut.ac.za }\end{array}$ \\
\hline $\begin{array}{l}\text { Dates: } \\
\text { Received: } 28 \\
\text { Accepted: } 26 \\
\text { Published: } 31\end{array}$ & $\begin{array}{l}\text { Aug. } 2015 \\
\text { Aug. } 2016 \\
\text { Mar. } 2017\end{array}$ \\
\hline $\begin{array}{l}\text { How to cite th } \\
\text { Mpwanya, M. } \\
\text { Heerden, C.H. } \\
\text { supply chain } \\
\text { framework fo } \\
\text { African mobil } \\
\text { industry', Sou } \\
\text { Journal of Eco } \\
\text { Management } \\
\text { a1464. https:/ } \\
\text { 10.4102/sajen }\end{array}$ & $\begin{array}{l}\text { is article: } \\
\text { F. \& Van } \\
\text { 2017, 'A } \\
\text { ost reduction } \\
\text { the South } \\
\text { phone } \\
\text { h African } \\
\text { nomic and } \\
\text { Sciences 20(1), } \\
\text { /doi.org/ } \\
\text { ns.v20i1.1464 }\end{array}$ \\
\hline $\begin{array}{l}\text { Copyright: } \\
\text { (c) 2017. The } \\
\text { Licensee: AOS } \\
\text { is licensed un } \\
\text { Creative Comr } \\
\text { Attribution Lio }\end{array}$ & $\begin{array}{l}\text { uthors. } \\
\text { S. This work } \\
\text { ler the } \\
\text { nons } \\
\text { ense. }\end{array}$ \\
\hline Read online: & \\
\hline 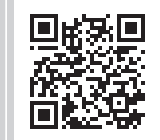 & $\begin{array}{l}\text { Scan this QR } \\
\text { code with your } \\
\text { smart phone or } \\
\text { mobile device } \\
\text { to read online. }\end{array}$ \\
\hline
\end{tabular}

Authors:

Musenga F. Mpwanya

elius $H$. van Heerden²

Affiliations:

Logistics and Sport

Management, Tshwane

University of Technology,

${ }^{2}$ Faculty of Management Sciences, Office of the

Executive Dean, Tshwane University of Technology,

Musenga Mpwanya,

Dates:

Accepted: 26 Aug. 2016

How to cite this article:

Mpwanya, M.F. \& Van

Heerden, C.H., 2017, 'A

pply chain cost reduction

African mobile phone

industry', South African

a1464. https://doi.org/

Copyright:

(C) 2017. The Authors.

is licensed under the

Creative Commons

Attribution License.

mobile device
to read online.
Background: The costs incurred in the provision of products and services across the supply chain are on the rise in many industries, including the mobile phone industry. Despite this, there is limited information in South Africa on the perceptions of supply chain players regarding cost reduction in the mobile phone industry. Furthermore, there is currently no framework for reducing supply chain costs in the South African mobile phone industry.

Aim: The purpose of this study is to explore supply chain costs in the South African mobile phone industry, and to develop a supply chain cost-reduction framework for the South African mobile phone industry.

Setting: This study explores supply chain costs in four mobile phone companies operating in the South African mobile phone industry, of which three mobile network operators and one mobile retailing group. It uses semi-structured interview data collected in 2011.

Method: This study adopted a qualitative case study design to understand supply chain costs and develop a supply chain cost-reduction framework for the South African mobile phone industry. Eight semi-structured interviews with managers of mobile phone companies were conducted. The data were analysed with the help of Atlas.ti, using an adapted three-phased analytical framework as suggested by Miles and Huberman (1994) and O' Dwyer (2004).

Results: The study found that consolidation of strategic relationships through collaboration and strategic alliances between MNOs and other supply chain players is one of the ways to drive costs down across the supply chain. Outsourcing of some of the support activities and retailers' direct purchasing transactions from device manufacturers were also found to be other avenues for reducing supply chain costs in the industry.

Conclusion: The study suggests that mobile network operators (MNOs) need to consolidate their strategic relationships by increasing the share of the network infrastructure, and emphasising the need to strive for operational efficiencies. This combined effort should result in significant cost reductions across the supply chain. The findings of this study provided some avenues that managers of mobile-phone companies could consider to drive costs down supply chain-wide and service end-users at lower rates. The findings of this study could also help regulating authorities to get insights into supply chain cost reduction and develop appropriate mobile phone policies in South Africa.

\section{Introduction}

Accurate information on supply chain processes is a key factor in managing costs in supply chains, and in gaining and sustaining a competitive advantage. However, operating expenses, like supply chain costs, expended by many companies, including mobile phone companies in the provision of products and services, are colossal. These costs impact on the tariffs paid by the endusers. This has led many companies to embark on cost reduction programmes supply chain-wide. AQUA Management Consulting Group (2008) outlines that cost reduction should be a continuous improvement commitment for companies seeking to meet their customers' demand for a better quality of products or services at a lower price.

Likewise, Fawcett, Ellram and Ogden (2007) state that implementing cost reduction as an isolated improvement programme would be ineffective, because cost reduction affects other functions, like the supply chain, and the firm's value proposition to its customers. Wagner, Erhun and GrossRuyken (2009) conducted a study on top supply chain challenges that motivate action in the United States and Europe. They identified cost reduction as one of the major supply chain challenges faced by manufacturing companies and one of the most powerful ways to increase profitability. The study also highlights a range of value-adding and improvement mechanisms 
that could be used to reduce supply chain costs. These mechanisms include process efficiencies, shorter cycle times and increased supply chain visibility, lean techniques, resource utilisation, as well as the elimination of unnecessary resources and lower inventory levels. Wisner, Tan and Leong (2009) agree with the above authors and state that cost reduction remains one of the top supply chain priorities. At its maturity stage, supply chains tend to focus on performance improvement in terms of identified cost reduction activities, using continuous improvement efforts, better supply chain communication and inventory visibility, and a further integration of business processes pertaining to waste, purchasing, distribution, inventory and non-value-adding activities among supply chain partners.

In an effort to drive costs down and to focus on the core business, several telecommunications network operators in the United States have used the shared-service model in some key functions (Katz \& Hamilton 2003). In a study by Sachan, Sahay and Sharma (2005), on developing a supply chain cost model in the Indian agricultural sector, the use of the system-dynamics grain supply chain model was suggested to reduce costs supply chain-wide. Research by $\mathrm{Wu}$ (2005) in the United States automatic test equipment industry found that architectural costs are hierarchically organised and interrelated. AQUA Management Consulting Group (2008) conducted its study in the Indian automotive industry. This study suggests that supply chain cost reduction can be achieved by maintaining balanced inventory levels, increased inventory returns and better resource utilisation. However, little is known on supply chain cost reduction in the South African mobile phone industry or in the rest of the world. More importantly, no public study has provided a supply chain cost reduction framework for the South African mobile phone industry. The research question posed for this study is: How can the South African mobile phone companies effectively reduce their costs supply chain-wide?

The purpose of this study is to develop a supply chain cost reduction framework for this industry. The rest of the article is organised as follows. 'The Literature Review' section includes background on cost in the telecommunication industry and on supply chain cost reduction models. 'The Research Methodology' section provides the methodologies followed to collect the data and answer the research question. 'The Findings' section' reports and discusses the findings and presents the proposed supply chain cost reduction framework for the South African mobile phone industry. And, the 'Conclusion' section is followed by the last section 'Managerial Implications and Recommendations'.

\section{Literature review}

\section{Cost in the telecommunication industry}

The telecommunications industry allocates enormous funds to operating expenditure (Opex). The major components of the overall cost include information technology, finance and sales and marketing (Katz \& Hamilton 2003). With regard to technology cost, Harmantzis, Trigeorgis and Tanguturi (2006) indicate that the telecommunication market requires substantial technological investment. Because of the speed in technology change, mobile phone companies are constrained to upgrade their network infrastructure and provide better service to their end-users.

Mishra et al. (2005) view Opex as the cost expended by mobile network operators (MNOs) for operating and maintaining the network infrastructure and for providing services to customers. It consists of labour costs, recurring power costs, licence fees and per call termination charges. Al-Debei and Avison (2009) and Peppard and Rylander (2006) point out that MNOs' Opex exceeds the capital expenditure (Capex) in value. Pattanavichai, Jongsawat and Premchaiswadi (2011) define Capex as the expenses incurred to purchase the physical resources needed for the upgrade of the telecommunication infrastructure. This includes the site construction cost, base station cost, switch cost, antenna cost, radio cost and the integration cost, which are expended for building a single cell site. However, although Capex is considered as 'a good indicator of the level of investment performed by MNOs' (IDATE Consulting 2015), high Capex with low return on investment has become another challenge faced by the telecommunication industry globally (Firli, Primiana \& Kaltum 2015; PWC Analysis 2012).

An MNO is a firm that owns a mobile network facility, and it provides mobile telecommunication services to customers (Jing \& Xiong-Jiang 2011). In addition to network connectivity that MNOs offer to their customers, Camponovo and Pigneur (2003) note that MNOs also offer a variety of networkrelated services, ranging from location information to user identification via billing services to customers. In the South African context, the business portfolio of MNOs includes network connectivity, starter packs and air times. This has contributed to the strength and dominance of MNOs over other players and to weak competition in the mobile phone industry. In order to address this situation, telecommunication policies need to be revisited.

In a global effort to increase competition and provide better service propositions to customers, many countries have embarked on more deregulations of the mobile phone space, which have led to the emergence of mobile virtual network operators (MVNOs). Kalmus and Wielhaus (2010) define an MVNO as a business entity that purchases capacity or minutes at wholesale rates from an $\mathrm{MNO}$ and then resells these under their brand label to customers. In this way, they avoid owning and operating their own mobile network facility. Song (2010) believes that MVNOs are vehicles that strengthen competition for various mobile services. He argues that the establishment of MVNOs should, in principle, increase retail competition and therefore reduce the prices of mobile services (Song 2010). However, in South Africa, the introduction of MVNO and the reduction of mobile termination rates through regulations have not yet fully translated into increased retail competition and lower mobile services to the end-users. 
Camponovo and Pigneur (2003) argue that given the central role of MNOs in the mobile telecommunication landscape, they should partner with other industry players including content providers, application providers, service providers (SPs), virtual operators and portals, in order to effectively fulfil their core business. Differentiating content providers and content enablers from SPs, Sabat (2002) pointed out that while application providers, also known as content enablers, determine the possible services that users should utilise when they are connected to the Internet network, or to other telecommunication networks, content providers offer tailormade and predetermined contents to the end-users. These are referred to in some circles as personalised contents, whereas mobile-wireless SPs ensure that users have access to mobile-wireless content via the networks. According to Brito and Pereira (2006), an SP is a firm that purchases air time from an $\mathrm{MNO}$ and then resells them to the final consumers.

Echoing collaboration, communication and co-operation, Al-Debei and Avison (2007) assert that the complexity of a value network is largely dependent on technological advances. These changes in technology require MNOs to establish collaboration, communication and co-operation in order to be effective. These authors go on to say that such collaboration among value network companies is critically important in enabling the acquisition of assets and the provision of any complementary services needed to meet the needs along the value network (Al-Debei \& Avison 2007). Stuhmeier (2012) argues that the rollout of long-term evolution (LTE), also known as fourth generation (4G), has caused MNOs to embrace collaboration on infrastructure building or use the infrastructure or network sharing approach. Lange (2012) views $4 \mathrm{G}$ as the highly advanced mobile technology.

In order to monitor supply chain cost effectively, it is important to understand what drives cost in organisations. Mowen, Hansen and Heitger (2009) view a cost driver as a causal factor that measures the output of the activity that causes cost changes to occur. Fawcett et al. (2007) point out that 'cost drivers vary over time and among different products and services'. According to Mowen et al. (2009), companies that identify and manage cost drivers are believed to be well positioned to ensure better cost forecasting and cost control. Many scholars classify Capex among the main cost drivers of the mobile phone industry (Harmantzis et al. 2006; Sabat 2002).

According to Machuca (2006), Capex and Opex make up network operators' total cost of ownership. Considering the ever-growing nature of Opex for the mobile telecommunications industry (Pattanavichai et al. 2011) and the increasing need for cost reduction in the mobile telecommunications industry globally, MNOs should revisit their total cost of ownership and decrease their Opex. A decrease in supply chain costs could be one of the keys in addressing the high costs of mobile services in the South African mobile phone industry.

\section{Supply chain cost reduction models}

The increasing need for reducing telecommunications costs has led several network operators in the United States to use the shared-service model for some key functions (Katz \& Hamilton 2003). Ulbrich (2006) describes shared services as a business approach that combines or consolidates services within an organisation. Bergeron (2003) argues that firms that implement the shared-service model have many benefits, including reduced costs (resulting from increased efficiencies, decreased personnel requirement and improved economies of scale), improved services, a greater focus on the firm's core activities and the externalisation of the potential profit centre.

The shared-service model can be used by a single firm or in a supply chain setting. In South Africa, because of pressure to reduce costs from the Independent Communication Authority of South Africa (ICASA), the MNOs have embarked on the shared-service model, whereby they have returned network infrastructure and its maintenance cost to manufacturers (suppliers). However, in comparison with other countries, several studies point out that mobile service costs in South Africa are still too high for the end-user (Chetty 2011; Research ICT Africa 2013).

Su and Lei (2008) proposed a theoretical supply chain cost reduction model containing four pillars, namely supply chain costing, improving processes, compressing supply chain time and smoothing the interfaces. Wisner et al. (2009) suggest that companies can reduce supply chain costs through waste reduction, purchasing and productdistribution costs, as well as excess inventories and nonvalue-adding activities among the supply chain participants. Anklesaria (2008) suggests two approaches to reducing supply chain costs, namely cost negotiation and breakthrough ideas. Cost negotiation is a multi-fold process. It begins with the creating of robust sourcing teams responsible for trading volume for price. This is followed by price monitoring that balances a buying firm's benefits against an industry pricing trend. To outdo the market trend and to sustain the price monitoring effort, graphs and maps relating to industry price trends are used against current prices charged for a range of specific products and services. On the contrary, the authors emphasise that breakthrough ideas lie in building and maintaining buyer-supplier collaborative relationships. Collaboration can provide many benefits to a buying firm if there is a strategic emphasis on managing supplier relationships.

To achieve significant savings in Capex and Opex, many mobile phone companies have embarked on a set of business agreements, including collaboration and outsourcing. According to Hasbani et al. (2009), telecom players need to combine outsourcing of operational functions (such as field operations and network services) with infrastructure sharing, in order to reduce their cost. Frisanco et al. (2008) argue that, for network operators who aim to reduce their operating costs through collaborative schemes, outsourcing becomes the right option. These authors point out some of 
the benefits associated with outsourcing, which include higher interactions (synergies) from services alignment, the facilitation of the sharing process, the provision of a neutral governance model and the protection of each operator's data (Frisanco et al. 2008).

Companies that outsource operational functions should not only aim to reduce costs but also to enhance effectiveness, so that high-standard products and services can be provided to their customers. Yu and Yang (2011) argue that efficiency can be successfully achieved in the business-chain system when MNOs outsource various content services from professional content providers. According to Frisanco et al. (2008), there is a need for full turnkey equipment and operation outsourcing to support network sharing efforts and to thereby increase savings on Capex and Opex. GSMA (2014) points out that

there have been some moves to introduce network sharing in South Africa, Nigeria and Ghana, but so far it has not been widely adopted by operators as a strategy to increase capacity and coverage. (p. 32)

Network sharing and reduction in capital and operating costs do position mobile phone companies not only for increased profitability but also for greater competitiveness and reduced mobile prices to end-users. Liao and Gonzalez (2009) maintain that for telecommunication companies to become more competitive and profitable, they should concentrate more on improving their productivity and efficiency. Similarly, Liao and Lin (2011) point out that although productivity and efficiency play a crucial role in competitive markets, companies need to know themselves in terms of their strengths and weaknesses, in order to alter their managerial efforts strategically, and to increase their efficiency and profitability. This could help them build and secure the competitive edge.

Outsourcing has driven many companies globally to become more efficient and cost reduction inclined or oriented (Marshall, Mc Ivor \& Lamming 2007). It is argued that outsourcing partners could consolidate their production processes to pave the way for better and lower-cost services to customers in countries that encourage outsourcing (Berkers et al. 2010).

When considering the supply chain cost models mentioned above, it should be noted that all of these models were designed for manufacturing industries. Because of this, a conceptual framework of relationships forming the basis for data collection and data analysis of this study is presented in Figure 1. This framework, which is service industry-oriented, is based on literature review and the use of a qualitative case study methodology.

\section{The development of the conceptual framework for this study}

The framework in Figure 1 shows the relationships among three major components, namely cost drivers, areas for cost reduction and cost reduction implementation in the South

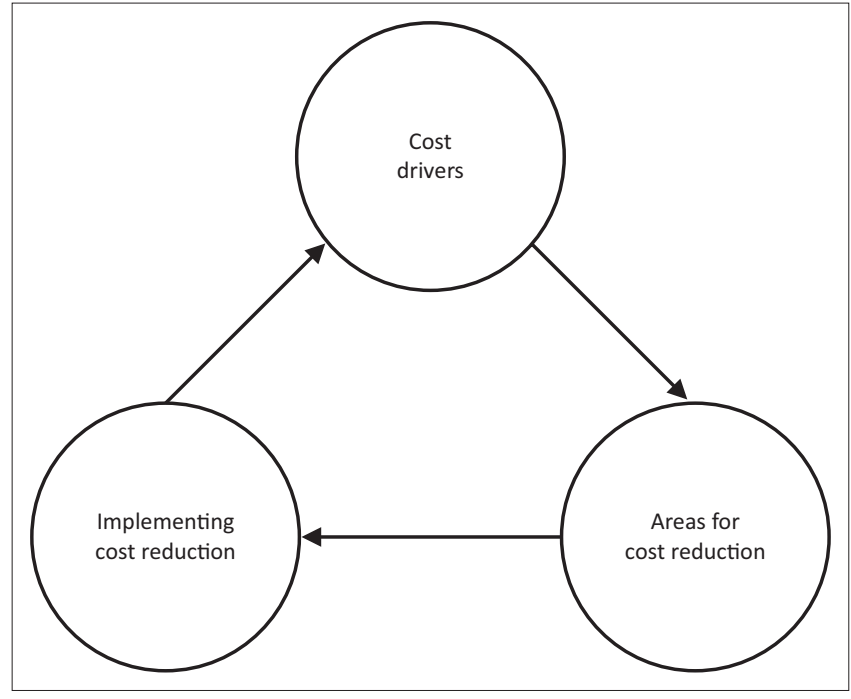

Source: Mpwanya, M.F., 2014, 'A supply cost reduction framework for the South African mobile phone industry', Doctoral thesis, Department of Marketing, Logistics \& Sport Management, Tshwane University of Technology, South Africa

FIGURE 1: A conceptual framework for supply chain cost reduction in the South African mobile phone industry.

African mobile phone supply chain. These components are instrumental in ensuring the effectiveness of mobile phone companies in South Africa.

\section{Cost drivers}

To achieve their organisational goals, mobile phone companies perform a set of activities and processes that generate costs. Failure to better understand these costs could result in a waste of resources and in high-input costs within the company. Consequently, it is important to first put in place a cost control mechanism that would identify and manage all the cost drivers of South Africa's mobile phone companies because these companies, like their counterparts elsewhere in the world, are known for their high operating costs.

\section{Area for cost reduction}

The identification of cost drivers should be followed by the identification of opportunities or possible areas for cost elimination or reduction because cost reduction efforts are related to the control of cost drivers for each activity performed by South Africa's mobile phone companies. The cost structure of mobile phone companies, particularly their operating costs could help identify possible areas for cost reduction. The identification of areas for cost reduction through cost driver analysis should culminate in elimination or reduction of non-value-adding activities and thereby enhancing value-adding activities and efficient processes and relationships among supply chain partners (mobile phone companies).

\section{Implementing cost reduction}

The climax of any process of re-engineering should be the implementation of cost reduction efforts, as all identified processes with high costs are either eliminated or reduced. Cost reduction is neither a one-time activity nor a linear process, but an ongoing improvement effort. Implementing 
cost reduction measures could enable South African mobile phone companies to become more efficient and better serve the end-users.

\section{Research methodology Nature of the study, selection of components and participants}

To gain insight into managers' perceptions relative to cost reduction in the South African mobile industry, this study has used a qualitative research approach with a single case study design focussing on supply chain players (components) in the South African mobile phone industry. In this study, the term 'case study' is used as the research method and as the unit of analysis (Nieuwenhuis 2007).

The initial selection of supply chain components for this study, framed from the supply chain literature review in the mobile phone industry, included device manufacturers, equipment vendors, content providers, content enablers, MNOs, the MVNO, SPs, mobile retailers and users. These are mobile phone players supply chain wise (Camponovo \& Pigneur 2003; Kalmus \& Wielhaus 2010; Sabat 2002), and the discussion on each of these players is out of the scope of this single article.

Because of the non-disclosure agreements with MNOs and the competition, some of the role players chose not to participate in this study. The final selection of participants for this study consisted of three MNOs, one SP and one mobile retailing group. Users were excluded from the final component selection as they could not provide significant insights regarding the study that deals with supply chain cost reduction by suppliers.

The participants mainly consisted of procurement managers and logistics managers for MNOs, a supply chain manager and a managing director for a retailing group and for the SP, respectively. They were all knowledgeable about the supply chain in the South African mobile phone industry and willing to participate in the study. The sampling was purposeful and aimed at gaining insightful information into supply chain cost reduction in the South African mobile phone industry. The interview protocol was developed from the literature review and included questions related to supply chain costs in the South African mobile phone industry. Prior to the data collection, a pilot case study involving interviews with two willing managers of MNOs was used to refine the interview protocol and to ensure that the interview questions and interview procedures were clear to the participants (Yin 2009). Convenience, access and geographic proximity were key criteria followed in selecting the participants in the pilot case study (Yin 2009).

\section{Data collection}

Eight semi-structured interviews were held from August 2011 to December 2011, involving six managers from three
MNOs (two managers per MNO from different branches), one manager from an SP and one manager from a retailing group, as illustrated in Table 1.

The interviews were all pre-arranged, conducted in English and audio-recorded. The average duration for interviews was 1 hour and 20 minutes. Interview transcriptions took place after each interview session and took into consideration field notes made during the interview sessions.

Saturation was reached with the MNOs' component at interview number six as the same responses were being received from the participants. On the contrary, saturation was hard to reach with the SP component and the mobile retailing group component because of the small number of willing participants interviewed - one participant for each component.

Besides semi-structured interviews, observation and documents were also used to gather the data. The observations mainly focused on participants' body language, discomfort and hidden meanings during the interview sessions. All these mind-revealing attitudes were noted and considered in the reporting and analysis of findings (Marshall \& Rossman 2011). Annual reports of MNOs and other published documents related to telecommunication costs were gathered in this study. These guided the first author in the identification of any potential issues to be addressed in the research questions. The collection of multiple types of data is well recognised in qualitative studies, and particularly in qualitative case studies (Baxter \& Jack 2008; Creswell 2009; Eisenhardt 1989).

\section{Validity, reliability and triangulation}

All eight semi-structured interviews were audio-recorded, transcribed verbatim and sent to the participants for validation and then returned to the researchers. As suggested by McKinnon (1988), the study also used probing to address any concerns relative to the validity and reliability in qualitative research. To further ensure validity and reliability, triangulation was also used (Hair et al. 2007; Willis, Jost \& Nilakanta 2007). Data triangulation was employed to compare and contrast the opinions of participants representing various supply chain components of the mobile phone industry. Method triangulation was also employed because multiple sources of evidence, including interviews, observations and documents, were used and compared.

TABLE 1: Participants' sample

\begin{tabular}{lccc}
\hline $\begin{array}{l}\text { Mobile phone } \\
\text { component }\end{array}$ & $\begin{array}{c}\text { Number of mobile } \\
\text { phone companies }\end{array}$ & $\begin{array}{c}\text { Number of managers per } \\
\text { mobile phone company }\end{array}$ & Total \\
\hline Network operators & 3 & 2 & 6 \\
Service providers & 1 & 1 & 1 \\
Retailing group & 1 & 1 & 1 \\
Total & & & 8 \\
\hline
\end{tabular}

Source: Mpwanya, M.F., 2014, 'A supply cost reduction framework for the South African mobile phone industry', Doctoral thesis, Department of Marketing, Logistics \& Sport Management, Tshwane University of Technology, South Africa 


\section{Data analysis}

Interview transcripts were analysed with the help of ATLAS. ti, using a three-phase process, as proposed by O'Dwyer (2004). This process, which is an adaptation of Miles' and Huberman's (1994) analytical framework, includes data reduction, data-display and data interpretation and conclusion-drawing. In the data reduction phase, the interview data per participant were transferred from the recording device to a desktop computer and labelled for confidentiality reasons. Each participant's interview data were carefully listened to and reviewed. This led to the emergence of preliminary themes, which were noted and refined at a later stage.

Next, all the transcripts were transferred from the desktop to ATLAS.ti (version 6.2) where they were coded with the help of ATLAS.ti using a bottom-up, inductive approach. The coding process in the data reduction stage and data-display stage was complex and lengthy. This led to or resulted in the creation of two types of codes, namely open codes and core codes. 104 open codes, known as initial codes, were created and represented loose themes. These codes were revisited and refined at a later stage in line with the research question of this study. In the quest for patterns and themes, similarities and contrasts were identified by means of the comparison of transcripts. The data-display phase identified links resulting from the data reduction phase through mind mapping. This helped link this study to previous studies on supply chain cost reduction conducted in various industries globally.

The themes resulting from the data reduction phase mirrored this study's research questions. Outlying statements were noted and matrices were constructed by using the 10 core codes created from the 104 open codes created in the data reduction stage. This helped in making comparisons between the different supply chain components of the South African mobile phone industry and to identify patterns in the data for refinement at the data interpretation and conclusion-drawing stage.

In the data interpretation and conclusion-drawing phase, the opinions of the participants were investigated, across and within the matrix, in order to build a holistic and comprehensive view of supply chain cost reduction in the South African mobile phone industry. Any standalone quotation that could contrast and challenge the comprehensively developed view was also noted. Next, the participants' thick descriptions and pertinent quotations were selected to indicate how the participants understand supply chain cost reduction in the South African mobile phone industry. According to Lincoln and Guba (1985), a thick description provides others with a database for the possible transfer of findings to other environments. As opposed to quantitative research that seeks statistical generalisation, this qualitative case study has attempted to develop an analytical generalisation as people are given the opportunity either to learn from the case for themselves or to apply to a population of cases (Creswell 2007).

\section{Findings}

The themes that emerged from the data analysis are discussed in relation to the available literature. For confidentiality purposes, pseudonyms are used for the participants and the names of the companies involved are also withheld. Various acronyms are used to link the opinions of supply chain players to their respective component in the South African mobile phone industry to each pseudonym (where $\mathrm{MNO}=$ mobile network operator, $\mathrm{SP}=$ service provider and $\mathrm{R}=$ retailer $)$.

To answer the research question 'how can South African mobile phone companies effectively reduce their costs supply chain-wide?', the following interview question was posed to participants: What approach could be used to reduce supply chain costs in the South African mobile phone industry?

\section{Perceptions on which approach could be used to reduce supply chain costs in the South African mobile phone industry}

The major themes emerging from the reporting of findings include the consolidation of strategic relationships, outsourcing and direct purchasing transactions from device manufacturers. Each of these factors is discussed below.

\section{Consolidation of strategic relationships}

Consolidation of strategic relationships emerged as one of the pathways to cost reduction in the South African mobile phone supply chain. This insight is captured in the following quotation from one of the participants:

'Earlier, I indicated that consolidation could be the answer if you could have one supply chain company, one warehouse that distributes all the handsets, so you could still order them. You still have the [names of network operators] that have their procurement; but all goes to one distribution centre; and all goes to one or more courier companies, speed delivery and start getting that synergy, you start sharing the towers and a lot more, then [you would] start seeing some real costs being taken out of the business.' [Timothy, MNO, Head of Logistics Department, 50-year-old male]

MNOs emphasise the consolidation of strategic relationships, in order to drive costs down supply chain-wide. To achieve this, both collaboration and strategic alliances are needed. The findings of several studies have shown how collaborative relationships of mobile players, particularly MNOs, could play a vital role in cost reduction. For instance, Frisanco et al. (2008) suggest that MNOs should share sites, in order to achieve a major reduction in Capex and Opex. In addition, Sabat (2008) asserts that for network operators to reduce their Capex and Opex, they might also consider entering into network sharing agreements, whereas each network operator still retains its licence to provide wireless voice and data services to its customers.

In the South African context, collaboration on both the technical and logistical sides is needed. On the technical side, South African MNOs should share more and more network 
facilities among them, particularly base stations, and they should shift the competition from network infrastructure to price. Besides the shared-service arrangements between equipment manufacturers and MNOs, a 'pay-as-you-sell' approach could also be negotiated, whereby device manufacturers are paid for only those devices that have been sold by MNOs. This approach, when applied, would challenge device suppliers to offer sought-after devices, or marketable devices, and they could thereby unburden the devices' purchasing costs for MNOs. Such a contractual approach could also be negotiated between MNOs and retailers.

On the consumer side, collaboration between MNOs should focus on the logistical aspect, particularly warehousing and distribution. MNOs could also share a single warehouse with effective delivery mechanism to respond to customers' demands or needs, rather than each MNO owning a warehouse, and the transportation costs of devices and network infrastructure-related equipment's, because they all purchase from the same equipment manufacturers and device manufacturers.

\section{Outsourcing}

Outsourcing emerged as one of the pathways to cost reduction in the South African mobile phone supply chain. This insight is captured in the following quotation from one of the participants:

'Uh, I think that probably rethinking the model of how we work, moving away from Peter Drucker's model, where in order to get a high margin, you have to have everything under your own roof... So, now in order to be more efficient, you have to outsource everything you don't need, not everything completely, but you can...' [Philetus, MNO, Senior Procurement Group Consultant, 45-year-old female]

Because of the high operating costs in the mobile phone industry, caused by the speed in technology change, as well as the constant upgrading of network facilities and service end-users at low mobile costs, mobile phone companies should revisit their business model by making their activities and processes more efficient. One of the ways to achieve this is through horizontal integration. Such horizontal integration would consist of outsourcing some activities to third-party logistics companies.

Marshall et al. (2007) pointed out how many companies adopt the outsourcing approach, in order to become more efficient and to reduce costs globally. In South Africa, as logistical activities and call-centre activities are performed in-house, MNOs might well outsource them from specialised SPs. Besides these two activities, MNOs should dedicate or invest more energy in their core activity, which is network connectivity. There is also a need for MNOs to revisit their network equipment and device-acquisition forecasting approach. Combining these activities could result in substantial costs reductions and a decrease in supply chain costs.
Direct purchasing transactions from device manufacturers

Direct purchasing transactions from device manufacturers emerged as one of the pathways to cost reduction in the South African mobile phone supply chain. This insight is captured in the following quotation from one of the participants:

'...The model suggested is that I, as [a] retailer [need] to buy
directly from original equipment manufacturers and sell
handsets to customers, who [would] decide whether to connect
with any network operator... They [network operators] need to
support the infrastructure that is directly linked to their core
business, which is to provide network.' [Raphael, R, Supply
Chain Manager, 40 -year-old male]

Currently, mobile retailing companies in South Africa purchase handsets from MNOs and sell them to end-users. This business model gives MNOs greater leverage over mobile retailers and thus increases the volume or size of purchasing costs because of the involvement of MNOs acting as intermediaries between device manufacturers and mobile retailers. To enhance efficiency from a retailer and end-user perspective, mobile retailers should be allowed to purchase handsets directly from the device manufacturers. This would drive costs down across the supply chain, and foster better deals for end-users.

Given the oligopolistic trend in the South African mobile phone industry, mobile phone companies need to embrace a broader operational outsourcing, in order to decrease their supply chain costs substantially. Regulating authorities should revisit the mobile telecommunications policies in South Africa by allowing retailing companies to deal directly with device manufacturers.

\section{Network diagram on supply chain cost reduction}

In order to grasp the different links among core codes, a network diagram on supply chain cost reduction was designed. Two phases took place, namely the first attempt of a network diagram on supply chain cost reduction and the final network diagram on supply chain cost reduction, as depicted in Figures 2 and 3. This helped, enlightened and guided in the development of the supply chain cost reduction framework for the South African mobile phone industry.

Through interview data immersion and the literature review of the mobile telecommunication industry, 21 core codes of the first attempt to create a network diagram on supply chain cost reduction, as shown in Figure 2, were reduced through merging to 10 major core codes to enlighten the various links among the core codes and to gain new insightful information into the supply chain cost reduction in the South African mobile phone space. The merging of core codes into major core codes were made based on relatedness and inseparability. For instance, core codes, such as IT and software, were merged into core-code 'technology'; network infrastructure, network maintenance, the voice and the data were merged into the core-code 'network', just to name few. 


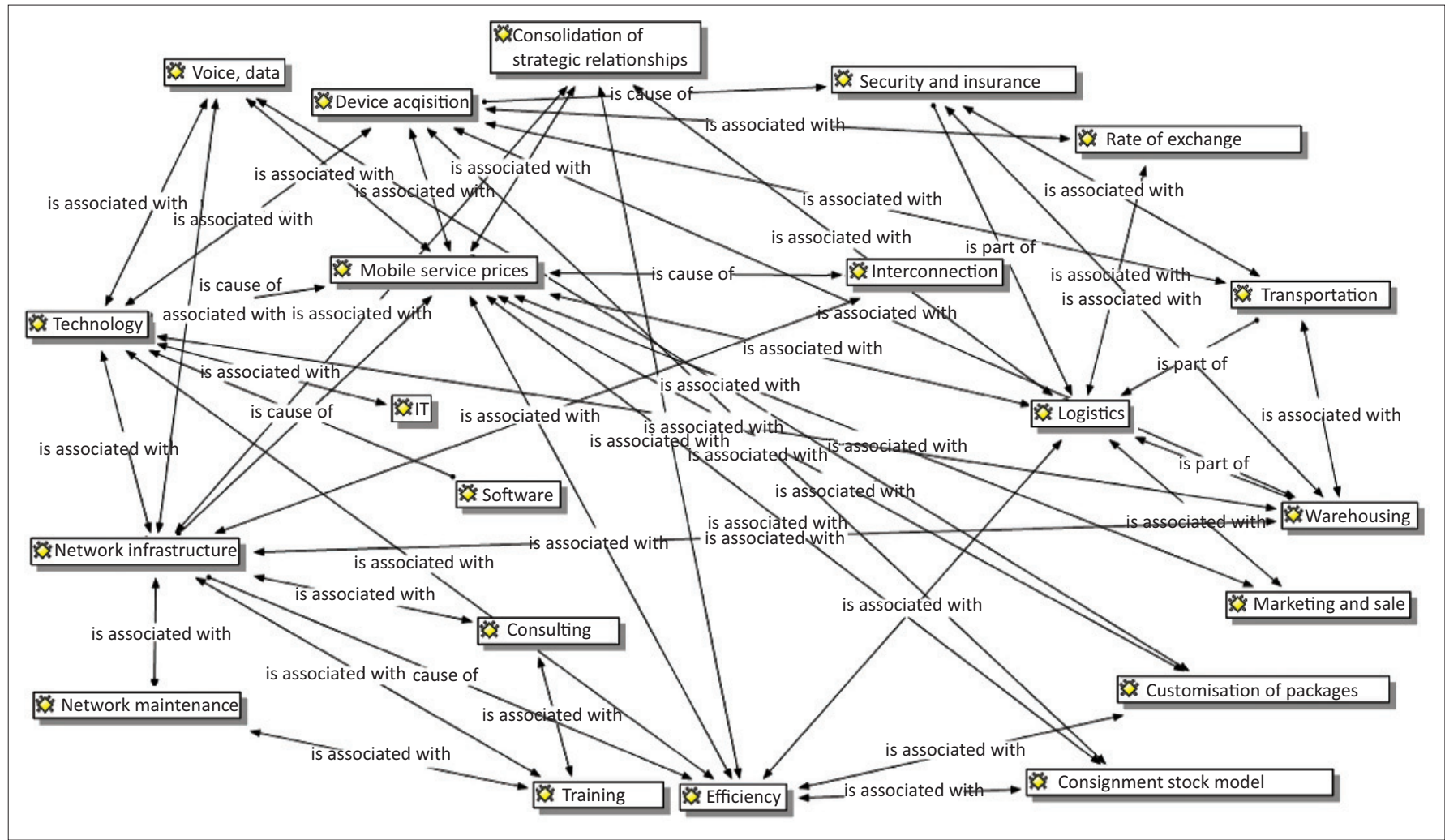

Source: Mpwanya, M.F., 2014, 'A supply cost reduction framework for the South African mobile phone industry', Doctoral thesis, Department of Marketing, Logistics \& Sport Management, Tshwane University of Technology, South Africa

FIGURE 2: First attempt to create a network diagram on supply chain cost reduction.

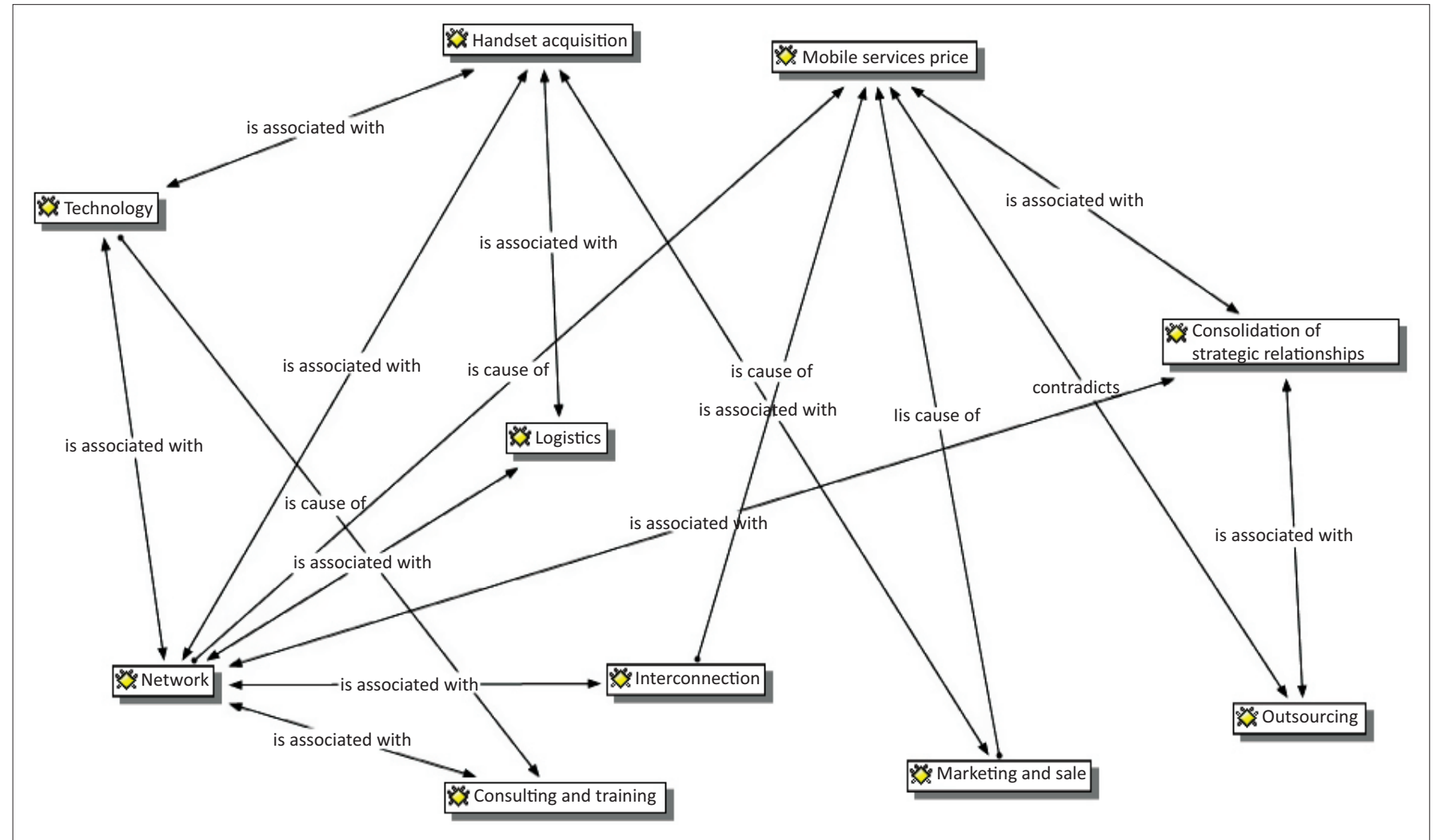

Source: Mpwanya, M.F., 2014, 'A supply cost reduction framework for the South African mobile phone industry', Doctoral thesis, Department of Marketing, Logistics \& Sport Management, Tshwane University of Technology, South Africa

FIGURE 3: Network diagram on the relationships between core codes. 
From the findings of this study, as discussed in 'Perceptions on which approach could be used to reduce supply chain costs in the South African mobile phone industry' and 'Network diagram on supply chain cost reduction' sections, multidimensional relationships between the various core codes or loosely categorised themes have emerged, and these are depicted in Figure 3. The relationships show the influence of core codes or loosely categorised themes on one another. The relationships also show the complexity of the core codes or loosely categorised themes relative to cost reduction in the South African mobile phone space from a supply chain perspective. However, it is important to note that a single article cannot suffice to discuss in detail each of these relationships or links, because of the volume of data regarding the relationships of different core codes of the final network diagram on supply chain cost reduction.

\section{The proposed framework}

From this study's findings, two main themes emerged in relation to cost reduction in South Africa's mobile phone supply chain, namely outsourcing and the consolidation of strategic relationships. These themes are pivotal for the development of the proposed supply chain cost reduction framework in the South African mobile phone industry, as depicted in Figure 4.

The multiplicity of companies and activities in the mobile phone supply chain makes mobile phone companies a complex part of the proposed supply chain cost reduction framework for South Africa's mobile phone industry. The interplay between MNOs and between MNOs and other mobile phone companies in the attainment of their core business and objectives helps to uncover a variety of links, as depicted in Figure 1-A1, (see Appendix 1). The figure shows a multiplicity of activities and relationships or links that mobile phone companies undertake in order to provide a variety of services to customers in the supply chain setting. A detailed discussion on each of the links in Figure 1-A1, (see Appendix 1) falls outside the scope of this article.

The interconnection between MNOs and between MNOs and fixed network operators plays a critical role in enabling end-users to communicate from the same network or on another network. This is facilitated by the help of the network infrastructure. The ability of an MNO's network infrastructure to provide continuous, reliable and quality mobile services and the decision relative to handset purchasing depends on the technology, because the mobile phone industry is technology-driven. To cope with the rapidly changing technology in the industry, foreign consulting services are used by MNOs to identify the latest working technology to be adopted, and foreign technical experts are employed in the training of local technical staff on the imported technology and network equipment.

Besides the logistical needs associated with imported network equipment, mobile phone companies are also responsible for the warehousing and distribution of handsets to various retailing outlets. This activity requires safety and security measures. The prices of mobile services are set, based on, among other factors, the network infrastructure, interconnection and marketing, and sales. One of the ways that can be used to service end-users at lower mobile prices is for mobile phone companies to embrace the consolidation of strategic relationships and learn to be efficient in their operations.

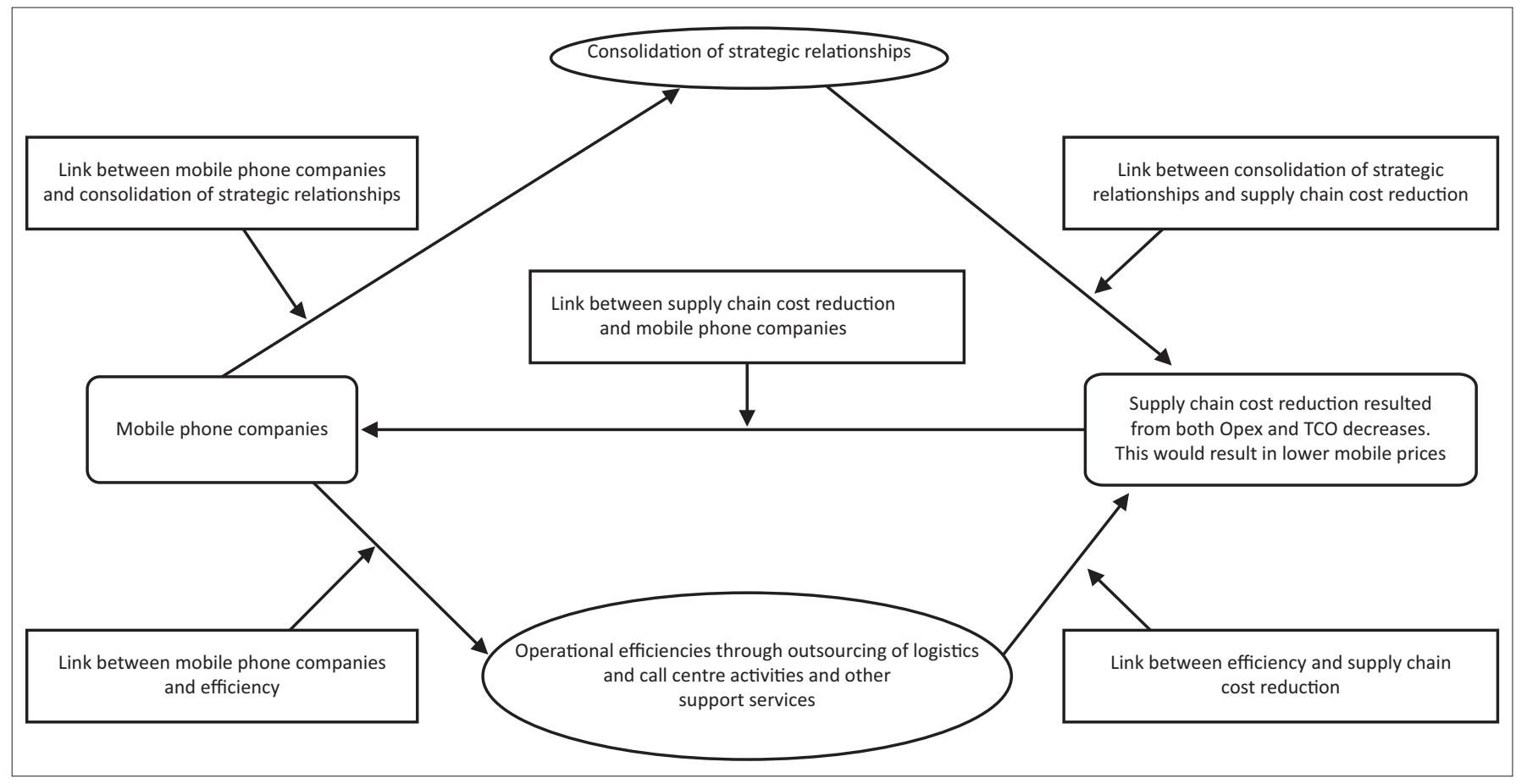

FIGURE 4: The proposed supply chain cost reduction framework for the South African mobile phone industry. 
Being the key players in South Africa's mobile phone supply chain, MNOs control the network infrastructure, the devices and SIM card businesses, and therefore, effective supply chain cost reduction requires the co-operatively synergised commitment and effort in the mobile phone supply chain, particularly with mobile phone companies. To achieve this, there is a need for consolidating relationships at the strategic level between MNOs and other mobile phone supply chain players in South Africa. These would include device manufacturers, equipment manufacturers, content providers, content enablers, the MVNO, retailers and SPs. The proper implementation of this business approach could trigger more synergy, effectiveness and significant cost reductions in the entire mobile phone supply chain.

MNOs should strive for better sourcing strategies to lower their purchasing costs. As they all purchase network equipment and devices from the same equipment manufacturers and device manufacturers abroad; they could, for instance, consider combining their network equipment and handset expenditures. It is tremendously important that MNOs should go a step further in identifying a set of areas that a handset manufacturer can provide and make various procurement deals - rather than purchasing single items, such as mobile devices. This might not only consolidate strategic relationships, but also pave the way for MNOs to become more effective and efficient in South Africa's mobile phone supply chain.

MNOs also need to seek operational efficiencies through the outsourcing of logistical activities from third-party logistical providers. These activities include warehousing, distribution, insurance and the security of purchased handsets. Additionally, they could also outsource all their call-centre services from third-party logistics providers. The outsourcing of both logistics and call-centre activities from third-party logistics providers would help MNOs save substantially on their Opex and decrease their supply chain costs in South Africa's mobile phone industry. This input into cost reduction through total cost of ownership supply chain-wide might, therefore, contribute to a reduction in call tariffs, on the one hand, and on the other hand, enhance competition because of various MNOs' business offerings.

Warehousing and call-centre facilities owned and managed by MNOs could be leased to other business organisations, and headcount costs (salaries and wages), electricity and other related operating costs would be saved. Other mobile phone companies (supply chain players) could also achieve operational efficiencies and the consolidation of strategic relationships - by outsourcing other non-core activities (support services), while increasing the focus on their core competences. The consolidation of strategic relationships with operational efficiencies by mobile phone companies would lead to higher synergies and greater supply chain cost reduction for South Africa's mobile phone industry and subsequently to lower mobile prices for end-users.
It should be indicated that the link between mobile phone companies and the consolidation of their strategic relationships, the link between mobile phone companies and outsourcing, the link between the consolidation of strategic relationships and supply chain cost reduction, the link between outsourcing and supply chain cost reduction, and the link between supply chain cost reduction and mobile phone companies were explored in the section dealing with the discussion on the findings.

Because of the speed of technology changes and the pressure for lower mobile service tariffs, mobile phone companies need to revisit their current business model and identify adequate technology to meet the various needs of end-users, while at the same time driving costs down supply chainwide. To this end, there is a need for more and more network infrastructural sharing and greater internal operational efficiencies.

\section{Managerial implications and recommendations \\ Managerial implications}

The study has highlighted some ways whereby managers of mobile phone companies could drive their supply chain costs down to service their end-users at lower prices. On the contrary, the findings of this study could help regulating authorities (i.e. The Independent Commission Authority of South Africa and the Department of Communications) to implement informed mobile phone policies that support and encourage the emergence and growth of local suppliers of telecommunication equipment and attract foreign investment in the industry.

\section{Recommendations}

The findings of this study single out MNOs as the most powerful players in the South African mobile phone supply chain because they have control of the three main streams of the mobile telecommunication business the network, handsets and starter packs. Additionally, compared with other players in the industry, MNOs necessitate huge spending on Opex, which is one of the contributors to high-cost mobile services, particularly call tariffs. To effectively drive their supply chain costs down, MNOs need to focus more and more on their core business, which is the provision of network connectivity, and to outsource non-core activities, such as logistics and callcentre services from specialised SPs. These steps would significantly lower the costs of warehousing management, security, insurance, headcount, transport and the maintenance of call-centre facilities. Other mobile phone companies should also focus on their core competences and outsource all other support services to decrease supply chain costs. This would result in considerable cost reductions across the supply chain and in better service offerings at lower prices for all the end-users. 
The Department of Communications and ICASA need to provide a robust regulatory framework that promotes intensive competition through the softening of entry barriers into the mobile phone industry. This would open doors for new entrants into the business and new approaches in terms of packages offered to customers and pricing. The Department of Communications and ICASA also need tailor-made telecommunication policies to support local suppliers of telecommunication equipment in building their technological capability. This initiative would address the dependence on the import of telecommunication equipment from foreign suppliers, which is costly and weighs heavily on the Capex of MNOs. Finally, the Department of Communications and ICASA need to find ways that would attract original equipment manufacturers to build their equipment plants in South Africa. This would reduce or eliminate equipment import costs.

\section{Conclusion}

Globally, mobile telecommunications is a capital-intensive and rapidly changing industry. Given the high Capex and Opex, and the increasing need of end-users for mobile communication services at lower prices, mobile phone companies need to revisit their business model and find ways to lower their Opex, while remaining profitable. One of the ways to achieve this is the decrease of costs supply chainwide. The study suggests that MNOs, the key players in the South African mobile phone supply chain, need to consolidate their strategic relationships with other supply chain players through increased sharing of the network infrastructure.

MNOs also need to strive for operational efficiencies by outsourcing their logistics and call-centre activities from specialised SPs. These combined actions should result in considerable supply chain cost reduction, which might also result in lower call tariffs to the end-users.

\section{Acknowledgements Competing interests}

The authors declare that they have no financial or personal relationships that may have inappropriately influenced them in writing this article.

\section{Authors' contributions}

This article is the outcome of a doctoral thesis presented and defended by M.F.M. at the Tshwane University of Technology under the supervision of C.H.v.H. the co-author.

\section{References}

Al-Debei, M.M. \& Avison, D., 2007, Business model requirements and challenges in the mobile telecommunication sector, viewed 12 September 2011, from http://www. researchgate.net/...telecommunication.../00b495252c86d6dc91000

Al-Debei, M.M. \& Avison, D., 2009, Business model requirements and challenges in the mobile telecommunication sector, viewed 27 January 2011, from http://bura. brunel.ac.uk/handle/2438/380/

Anklesaria, J., 2008, 'Shared value chain cost reduction through innovative supplier relationships', in Institute of Supply Management's 93rd Annual International Supply Management Conference, May, St Louis, MO, viewed 23 May 2010, from http://www.ism.ws/files/Pubs/Proceedings/BGAnklesaria.pdf
AQUA Management Consulting Group, 2008, Supply chain cost reduction in India. Supply chain cost reduction opportunities for Indian companies, Special report, viewed 15 February 2012, from http://www.aquamcg.com/DesktopModules/ ListingOfEvents/UploadFile/633773271593028750Supply_Chain_Cost ListingOfEvents/Upload

Baxter, P. \& Jack, S., 2008, 'Qualitative case-study methodology: Study design and implementation for novice researchers', The Qualitative Report 13(4), 544-559.

Bergeron, B., 2003, Essentials of shared services, Wiley, New York.

Berkers, F., Hendrix, G., Chatzicharistou, I., De Haas, I. \& Hamera, D., 2010, 'To share or not to share? Business aspects of network sharing for mobile network operators', in Proceedings of the 14th International Conference on Intelligence in Next Generation Networks (ICIN), Berlin, October 11-14, viewed 12 June 2013 from http://ieeexplore.ieee.org/stamp/stamp.jsp?tp=\&arnumber=5640887

Brito, D. \& Pereira, P., 2006, Mobile virtual network operators: Beyond the hyperbolae, viewed 11 October 2010, from http://www.concorrencia.pt/download/WP/5_ MVNO_Hype_Oct06.pdf

Camponovo, G. \& Pigneur, Y., 2003, 'Business-model analysis applied to mobile business', in 5th International Conference on Enterprise Information Systems, Angers, Maine-et-Loire, France, April 23-26, viewed 04 September 2012, from http://www.hec.unil.ch/gcampono/publications/GC2003ICEIS.pdf

Chetty, S., 2011, 'Processes for regulating interconnection rates in India and South Africa', Master's dissertation, School of Economics \& Business Sciences, University of the Witwatersrand, South Africa.

Creswell, J.W., 2007, Qualitative inquiry and research design. Choosing among five approaches, 2nd edn., Sage, Thousand Oaks, CA.

Creswell, J.W., 2009, Research design: Qualitative, quantitative and mixed-methods approaches, 3rd edn., Sage, Los Angeles, CA.

Eisenhardt, K., 1989, 'Building theories from case-study research', Academy of Management Review 14(4), 532-550.

Fawcett, S.E., Ellram, L.M. \& Ogden, J.A., 2007, Supply chain management. From vision to implementation, Pearson International edition, Pearson Prentice Hall, Upper Saddle River, NJ.

Firli, A., Primiana, I. \& Kaltum, U., 2015, 'The impact of increasing CAPEX on customer number, profit, and ROI in Indonesia telecommunication industry', American Journal of Economics 5(2), 135-138.

Frisanco, T., Tafertshofer, P., Lurin, P. \& Ang, R., 2008, 'Infrastructure sharing and shared operations for mobile-network operators', in Network Operations and Management Symposium, Salvador, Bahia, Brazil, April 7-11, viewed and Management Symposium, Salvador, Bahia, Brazil, April 7-11, viewed
02 September 2010, from http://ieeexplore.ieee.org/stamp/stamp.jsp? arnumber $=04533455$

GSMA, 2014, Mobile economy. Sub-Saharan Africa 2014, viewed 15 March 2016, from http://www.gsmamobileeconomyafrica.com/GSMA_ME_SubSaharanAfrica_ Web_Singles.pdf

Hair, J.F., Money, A.H., Samouel, P. \& Page, M., 2007, Research methods for business, Wiley, Chichester.

Harmantzis, F.C., Trigeorgis, L. \& Tanguturi, V.P., 2006, Flexible investment decisions in the telecommunications industry: Case applications using real options, viewed 12 September 2011, from http://archive.nyu.edu/bitstream/2451/.../HarmantzisTrigeorgis_06-06.pdf.txt

Hasbani, G., Weichsel, P., Trimmel, D. \& Cockburn, S., 2009, After the downturn: The four trends that are shaping telecom's future, Booz \& Co, viewed 11 September 2012, from http://www.booz.com/media/uploads/after_the_downturn.pdf

IDATE Consulting, 2015, Mobile operators' investments. Europe needs a proinvestment mobile regulatory framework, Whitepaper based on IDATE study for Ericsson and Qualcomm, viewed 12 April 2016, from http://www.ericsson.com/ res/docs/2015/mobile-operators-investments-whitepaper.pdf

Jing, Z. \& Xiong-Jian, L., 2011, 'Business ecosystem strategies of mobile network operators in the 3rd era: The case of China Mobile', Telecommunications Policy 35 156-171. https://doi.org/10.1016/j.telpol.2010.12.009

Kalmus, P. \& Wiethaus, L., 2010, 'On the competition effects of mobile virtual network operators', Telecommunications Policy 34(5\&6), 262-269. https://doi.org/10.1016 /j.telpol.2010.04.002

Katz, R.L. \& Hamilton, B.A., 2003, Remedies for telecom recovery project. Managerial strategies recommendations, Final report, Columbia Business School, viewed 20 June 2013, from http://www.citi.columbia.edu/CITI_Managerial advisorycomm.pdf

Lange, P., 2012, South Africa: Telecoms, mobile, broadband and forecasts, Executive summary, The continent's leading telecoms and digital media market, viewed 13 April 2013, from http://www.buddeComm.mht

Liao, C.H. \& Gonzalez, D.B., 2009, 'Comparing operational efficiency among mobile operators in Brazil, Russia, India and China', China \& World Economy 17(5), 104120. https://doi.org/10.1111/j.1749-124X.2009.01169.x

Liao, C.H. \& Lin, H.Y., 2011, 'Measuring operational efficiency of mobile operators in Japan and Korea', Japan and the World Economy 23, 48-57. https://doi.org/ 10.1016/j.japwor.2010.11.001

Lincoln, Y.S. \& Guba, E., 1985, Naturalistic inquiry, Sage, Beverly Hill, CA.

Machuca, C.M., 2006, 'Expenditure study for network operators', in International Conference on Transparent Optical Networks, Nottingham, Nottinghamshire, UK, June 18-22, viewed 16August 2010, from http://ieeexplore.ieee.org/stamp/ stamp.jsp?tp=\&arnumber $=4013626$

Marshall, C. \& Rossman, G.B., 2011, Designing qualitative research, 5th edn., Sage, Thousand Oaks, CA. 
Marshall, D., Mc Ivor, R. \& Lamming, R., 2007, 'Influences and outcomes of outsourcing: Insights from the telecommunications industry', Journal of Purchasing and Supply Management 13, 245-260. https://doi.org/10.1016/j. Purchasing and Supply
pursup.2007.07.001

Mckinnon, J., 1988, 'Reliability and validity in field research: Some strategies and tactics', Accounting, Auditing and Accountability Journal 1(1), 34-54. https://doi. tactics, Accounting, Auditing and Acc
org/10.1108/EUM0000000004619

Miles, M.B. \& Huberman, M.A., 1994, An expanded sourcebook. Qualitative data analysis, 2nd edn., Sage, Thousand Oaks, CA.

Mishra, S.M., Hwang, J., Filippini, D. \& Moazzami, R., 2005, Economic analysis of networking technologies for rural developing regions, viewed 12 June 2013, from http://www.cs.nyu.edu/ lakshmi/wine.pdf

Mowen, M.M., Hansen, D.R. \& Heitger, D.L., 2009, Cornerstones of manageria accounting, 3rd edn., International Student edition, South-Western, Mason, $\mathrm{OH}$.

Mpwanya, M.F., 2014, 'A supply cost-reduction framework for the South African mobile phone industry', Doctoral thesis, Department of Marketing, Logistics \& Sport Management, Tshwane University of Technology, South Africa.

Nieuwenhuis, J., 2007, 'Analysing qualitative data', in K. Maree (ed.), First steps in research, pp. 99-121, Van Schaik Publishers, Hatfield.

O'Dwyer, B., 2004, 'Qualitative data analysis: Illuminating a process for transforming a "messy" but "attractive" nuisance', in C. Humphrey \& B.H.K. Lee (eds.), The real life guide to accounting research: $A$ behind the scenes view of using qualitative research methods, pp. 391-407, Elsevier Limited, Oxford, UK.

Pattanavichai, S., Jongsawat, N. \& Premchaiswadi, W., 2011, 'Real options analysis for valuing strategic investments and decisions of the mobile virtual network operator's investment in E-UMUTS', in 9th International Conference on ICT and
Knowledge Engineering, Bangkok, Thailand, January 12-13, viewed 06 Keptember 2012, from http://www.ieeexplore.ieee.org/stamp/stamp.jsp?tp=\& arnumber $=6152394$

Peppard, J. \& Rylander, A., 2006, 'From value chain to value network: Insights from mobile operators', European Management Journal 24(2-3), 128-141. https://doi. org/10.1016/j.emj.2006.03.003

PWC Analysis, 2012, We need to talk about Capex. Benchmarking best practice in telecom capital allocation, viewed 12 December 2013, from https://www. pwc.com/gx/en/communications/publications/assets/pwc_capex_final_ 21may12.pdf

Research ICT Africa, 2013, Benefits of reduced termination rates finally kick in with lower mobile prices, viewed 12 December 2013, from http://www. researchictafrica.net/.../SA Policy_Brief_2013 No_1_FINAL_WE
Sabat, H.K., 2002, 'The mobile wireless supply chain', Productivity 42(4), 550-563.

Sabat, H.K., 2008, 'Spectrum-acquisition strategies adopted by wireless carriers in the USA', Information Systems Frontiers 10, 77-102. https://doi.org/10.1007/s10796007-9056-1

Sachan, A., Sahay, B.S. \& Sharma, D., 2005, 'Developing Indian grain supply-chain cost model: A system dynamics approach', International Journal of Productivity and Performance Management 54(3), 187-205. https://doi.org/10.1108/174104005 10584901

Song, J.-D., 2010, 'Various wholesale price equilibria for mobile virtual network operators', Telecommunications Policy 34,633-648. https://doi.org/10.1016/j. telpol.2010.07.002

Stuhmeier, T., 2012, 'Roaming and investments in the mobile internet market', Telecommunications Policy 36, 595-607. https://doi.org/10.1016/j.telpol.2012. 03.006

Su, T.Y. \& Lei, X.H., 2008, 'Research on supply chain cost reduction based on process and time analysis', Proceedings of the 2008 IEEE International Conference on Industrial Engineering and Engineering Management, Singapore, December 8-11, viewed 13 June 2013, from http://ieeexplore.ieee.org/stamp/stamp.jsp?tp=\& arnumber $=4738147$

Ulbrich, F., 2006, 'Improving shared service implementation: Adopting lessons from the BPR movement', Business Process Management Journal 12(2), 191-205. https://doi.org/10.1108/14637150610657530

Wagner, S.M, Erhun, F. \& Cross-Ruyken, P.T., 2009, Dressing for the weather: Top supply chain challenges motivate action, viewed 17 August 2009, from http:// www.entrepreneur.com/tradejournals/article/194529463.htm

Willis, J.W., Jost, M. \& Nilakanta, R., 2007, Foundations of qualitative research. Interpretive and critical approaches, Sage, Thousand Oaks, CA.

Wisner, J.D., Tan, K.C. \& Leong, G.K., 2009, Principles of supply-chain management. A balanced approach, 2nd edn., International Student Edition, South-Western , Mason, $\mathrm{OH}$.

Wu, C., 2005, 'Total supply-chain cost model', M.B.A. and MSc thesis, Massachusetts Institute of Technology.

Yin, R.Y., 2009, Case-study research: Design and methods, 4th edn., Sage, Thousand Oaks, CA.

Yu, K. \& Yang, Y., 2011, 'Study on the innovation capability of mobile communications industry in China', in 2nd International Conference on Emergency Management 2012, from http://ieeexplore.iee.org/stamp/stamp.jsp?tp=\&arnumber=6015793 


\section{Appendix 1}

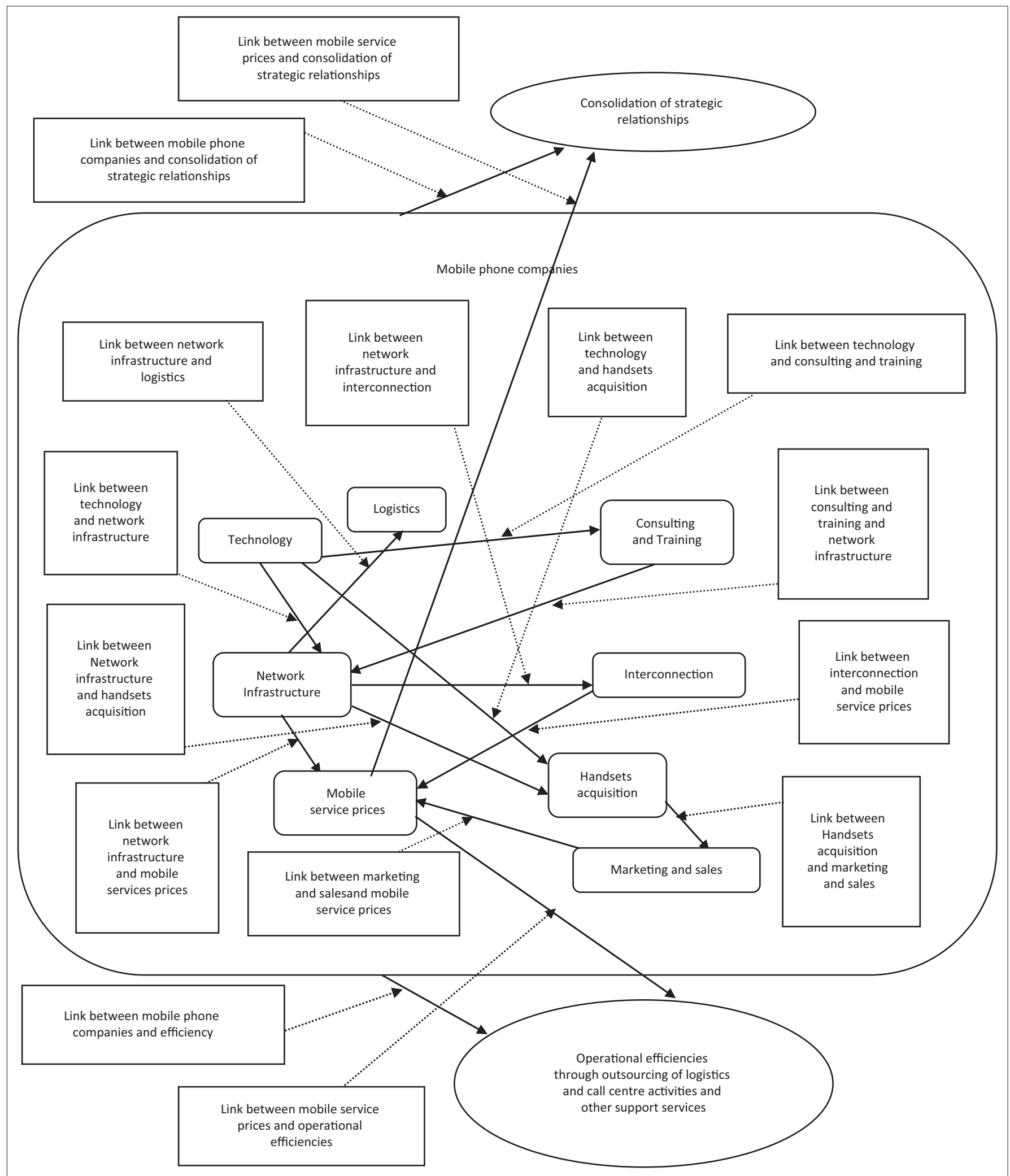

Figure 1-A1: Complexity of mobile phone companies and the associated links. 